NBER WORKING PAPER SERIES

\author{
APPLICATION OF NATIONALITY- \\ ADJUSTED NET SALES AND VALUE \\ ADDED FRAMEWORK: THE CASE \\ OF JAPAN
}

Fukunari Kimura

Robert E. Baldwin

NBER Working Paper 5670

\author{
NATIONAL BUREAU OF ECONOMIC RESEARCH \\ 1050 Massachusetts Avenue \\ Cambridge, MA 02138 \\ July 1996
}

The authors gratefully acknowledge financial support from the Ford Foundation and Keio University. We wish to thank Michael Plummer, Robert Lipsey, and other participants in the NBER conference for constructive comments. We would also like to thank Yoko Sazanami, Shujiro Urata, and other colleagues in a number of seminars in Japan. This paper is part of NBER's research program in International Trade and Investment. Any opinions expressed are those of the authors and not those of the National Bureau of Economic Research.

(C) 1996 by Fukunari Kimura and Robert E. Baldwin. All rights reserved. Short sections of text, not to exceed two paragraphs, may be quoted without explicit permission provided that full credit, including (C) notice, is given to the source. 


\title{
APPLICATION OF NATIONALITY- ADJUSTED NET SALES AND VALUE ADDED FRAMEWORK: THE CASE OF JAPAN
}

\begin{abstract}
This paper applies the nationality-adjusted net sales and value added framework proposed in Baldwin and Kimura (1996) to Japan. Despite possibly large estimation errors due to statistical deficiencies, the framework is very useful for analyzing the relationship of the Japanese economy to the world economy. We find that Japan is special in the following four aspects. First, Japaneseowned firms have become increasingly dependent on the marketing activities of their foreign affiliates, rather than depending on cross-border exports by parent firms located in Japan. Second, the much smaller activities of Japanese affiliates of foreign firms (JAFF) relative to those of foreign affiliates of Japanese firms (FAJF) are apparent in terms of sales, value added, and employment, at both the macroeconomic and sectoral levels. Third, Japanese net sales to foreigners are consistently larger than cross-border net exports of Japan. Fourth, among the activities of FAJF, the importance of commercial FAJF is particularly large; these commercial FAJF handle a large portion of Japanese exports and imports.
\end{abstract}

The paper concludes by discussing a number of statistical improvements required by the Japanese government in order to apply our analytical framework more rigorously.

Fukunari Kimura

Department of Economics

Keio University

2-15-45 Mita, Minato-ku

Tokyo

JAPAN
Robert E. Baldwin Department of Economics University of Wisconsin-Madison Madison, WI 53706 and NBER 


\section{Introduction}

In the companion paper for the United States (Baldwin and Kimura (1996)), we propose a nationality-adjusted net sales and value-added framework and apply it to United States data in order to show its usefulness in analyzing a number of current economic issues and to specify points for statistical improvements. The framework should eventually be expanded to an internationally integrated statistical system that captures the entire activities of multinational enterprises in the world. As a preliminary effort, this paper applies the framework to Japan.

The proposed framework analyzes the globalization of firms' activities from a new viewpoint. The traditional balance of payments (BOP) statistics conceptually presents international transactions between economic agents in different locations, a framework consistent with GDP or national accounts statistics. ${ }^{1}$ Since the BOP format primarily follows the residency of economic agents, the value added of foreign affiliates is conceptually decomposed into a residents' portion and a nonresidents' portion, with the latter portion being captured as investment income (including retained earnings). Thus, the BOP framework is not very convenient in analyzing the behavior of globalized firms'. Merchandise and services transactions between parent companies and affiliates may be qualitatively different from usual transactions between domestic firms and foreign firms. A firm may have its own resources for competitiveness, such as firm-specific technologies and managerial abilities, that can be used both inside and outside of the home country. Furthermore, even if a firm has multiple establishments across the world, it may make managerial decisions jointly. Our proposed 
framework assigns nationalities to firms and treats each firm as an individual entity. By doing so, we can analyze the competitiveness of firms in international markets, the importance of foreign-controlled affiliates in a national economy, firms' decisions on whether to export or to invest abroad, and other related issues. These features of firms' activities are particularly important in the case of Japan where firms' activities have been rapidly globalized.

Although Japan is one of the few countries that collect extensive operational data on inward and outward direct foreign investment (DFI), we still encounter a number of problems in applying the framework. We try to identify explicitly various statistical deficiencies in the available data and relate them to the proposed statistical format. However, despite large possible estimation errors, we believe that the framework is very useful for analyzing the relationship of the Japanese economy to the world economy. Our analysis confirms the oftenclaimed asymmetry between inward and outward DFI of Japan. We also find a rapid expansion of Japanese firms' activities abroad that exceeds the expansion of exports. In addition, we show that the activities of commercial affiliates of Japanese firms abroad, particularly those of general trading companies, play an important role in Japanese international transactions.

In the next section, the existing data for Japanese inward/outward DFI are briefly explained. Sections III and IV present our estimation of aggregate and sectoral net sales by Japanese to foreigners and the value added of foreign affiliates. Section $\mathrm{V}$ provides a preliminary overview on commercial affiliates of Japanese firms, which are specific to Japan and must be taken into consideration in developing an internationally integrated statistical format. Section VI summarizes what is special for Japan and discusses directions for the improvement of the statistical format. 


\section{Data on sales and purchases by affiliates}

A MITI data set (hereinafter referrerd to as "the old FAJF series") is the only currentlyavailable source for time-series data on the sales and purchases of foreign affiliates of Japanese firms (FAJF). The International Enterprises Section of MITI annually distributes questionnaires to parent Japanese companies that are identified by the Foreign Exchange and Foreign Trade Control Law as having foreign affiliates with more than a $10 \%$ share. $^{2} \mathrm{~A}$ detailed survey was initiated in 1980 and has been conducted every three years since 1983. A shortened questionnaire is used in the other years. Among the particularly useful information collected is data on purchases by FAJF (such data are not collected in the U.S. surveys of foreign direct investment). ${ }^{3} \quad$ This survey, however, is so-called shounin toukei, which means "approved statistics," and it is not legally mandatory for firms to fill in the questionnaire. Therefore, the data are much less reliable than the U.S. data. A serious problem is low coverage. For example, in 1992 , only $65.5 \%$ of the questionnaires sent to foreign affiliates were returned to MITI. Moreover, not all firms returning the questionnaire answered all of the questions. To make matters worse, MITI does not report the number of firms that answered each question. This problem is particularly serious for purchases data. In addition, not all firms that provide total sales or purchases data report by-destination disaggregation of sales or by-origin disaggregation of purchases.

The Research and Statistics Department of the Minister's Secretariat of MITI has recently begun to publish another statistical series covering FAJF. This survey called the Basic Survey of Business Structure and Activity (hereinafter "the new FAJF series"), collects data on FAJF as a part of information obtained on private firms' activities in Japan. The new series 
is so-called shitei toukei, which means "designated statistics," and therefore companies have a legal obligation to return completed questionnaires. The survey was scheduled to be conducted annually beginning in 1995. Since the figures for the 1991 financial year were not published until December 1994, we have figures for only one year thus far. Table 1 presents the 1991 financial year data on the activities of FAJF from the two sources, the old and new FAJF series. The new FAJF series provides more reliable figures than the old FAJF series, but the coverage is narrower and biased toward large companies. ${ }^{4}$

Data on Japanese affiliates of foreign firms (JAFF) are also reported by the International Enterprises Section of MITI. The structure of this survey is basically the same as that of the old FAJF survey. The coverage is, however, even narrower; for the 1992 financial year, for instance, only $53.7 \%$ of the questionnaires were returned to MITI. ${ }^{5}$

Another difference between the MITI and BEA data is that the former data set does not report sales of goods and services separately. In particular, the questionnaire by the International Enterprises Section of MITI does not explicitly specify sales and purchases as "sales and purchases of goods and services" so that we are not sure if firms report services transactions. Therefore, in our estimations, we tentatively use merchandise trade (not including services trade) for cross-border trade data.

\section{Estimation of aggregate net sales}

(1) Defining nationalities

MITI's old FAJF series defines foreign affiliates of Japanese firms (FAJF) as firms in which Japanese have more than a $10 \%$ share and majority-owned affiliates as firms in which 
Japanese have more than a $50 \%$ share. For our purposes, it is better to use the data for majority-owned affiliates, but they are not available in time series form. ${ }^{6}$ Thus, we define FAJF as firms in which Japanese have more than a $10 \%$ share. This may cause considerable measurement errors, particularly since it is a common practice for general Japanese trading companies to participate in a joint venture between Japanese and foreign companies as a third party with a minor share. For inward DFI, MITI's JAFF series defined Japanese affiliates of foreign firms (JAFF) as majority-owned affiliates until the 1990 financial year and as affiliates with more than one-third shares in the 1991 and 1992 financial years.

As in the case of the United States, we do not have data on sales and purchases by foreign citizens in Japan and those by Japanese living abroad. It is therefore necessary to classify households on a country-of-residence basis rather than on a nationality basis.

The term, "Japanese," thus consists of Japanese-owned firms in Japan and abroad, households of Japanese and private foreign citizens residing in Japan (Japanese-resident households), and Japanese government units. Similarly, the term, "foreigners," consists of foreign-owned firms in Japan and abroad, households of foreign and Japanese citizens residing abroad (foreign-resident households), and foreign governments.

(2) Estimates of net sales of Japanese to foreigners

Table 2 presents estimates of the net sales of Japanese to foreigners for 1987-1992. The table consists of (I) cross-border sales to and purchases from foreigners by Japanese, (II) sales to and purchases from foreigners by FAJF, and (III) Japanese sales to and purchases from JAFF (also see Figure 1). 
In Part I, Japanese cross-border sales (exports) to foreigners are estimated by subtracting the sum of Japanese exports shipped to FAJF and Japanese exports shipped by JAFF from cross-border exports of Japan valued on an f.o.b. basis. The estimate of such crossborder sales (exports) in 1987, for example, is 11,714 billion yen, which is much smaller than Japan's cross-border exports of 33,315 billion yen.

Quite aside from the above-mentioned coverage problem, the 11,714 billion yen figure is, for several reasons, still only an approximate estimate. The most serious problem is that the figure for Japanese exports shipped to FAJF (20,571 billion yen) is a very rough estimate. Among FAJF reporting the total amount of purchases are many that do not provide purchase figures disaggregated by origin, i.e., a considerable portion of FAJF do not report separately local purchases, purchases from Japan, and purchases from third countries. In 1987, for example, only $38.4 \%$ of total purchases by FAJF can be disaggregated by origin. We, hence, first calculate the ratio of purchases from Japan to total purchases for firms in each sector reporting purchases by origin. Then we multiply that ratio by total purchases by all firms in the sector and sum up all sectors' estimates of purchases from Japan. Another potential estimation problem concerns the treatment of purchases by FAJF from commercial FAJF. When an FAJF in the commercial sector imports intermediate goods and sells them to a noncommercial FAJF, both the commercial and non-commercial FAJF may treat these purchases as purchases from abroad. This means that the purchases ratios from Japan (and those from third countries) may be overstated to some extent. The estimation of purchases by FAJF from Japan or Japanese exports shipped to FAJF (20,571 billion yen) in 1987, may therefore differ from the true figure. In addition, exports by JAFF to FAJF are subtracted twice in this 
calculation since they are included in both Japanese exports shipped to FAJF and Japanese exports shipped by JAFF. This, however, probably does not affect our estimates very much. ${ }^{7}$

The lower half of Part I of Table 2 shows our estimates of Japanese cross-border purchases (imports) from foreigners, namely, 9,622 billion yen in 1987. These are again much smaller than cross-border imports $(21,737$ billion yen). They are calculated by subtracting the sum of Japanese imports shipped by FAJF and Japanese imports shipped to JAFF from Japanese cross-border imports valued on a c.i.f. basis. Again, the estimates of Japanese imports shipped by FAJF or sales to Japan by FAJF (9,294 billion yen) may contain large enrors. Since a large portion of FAJF do not report by-destination disaggregation of their sales (to the local market, to Japan, or to third countries), sales by FAJF to Japan are estimated by calculating the ratio of sales to Japan to total sales for each industrial sector, multiplying this ratio by total sales of the sector, and summing up all sectors' estimates of sales to Japan. Again, the ratios of sales to Japan to total sales may be overstated due to double-counting in the transaction through commercial FAJF. In addition, Japanese imports from FAJF shipped to JAFF are subtracted twice. ${ }^{8}$

By subtracting 9,622 billion yen from 11,714 billion yen, we obtain Japanese net crossborder sales to foreigners, 2,093 billion yen in 1987. Our estimates are consistently smaller than the cross-border trade balance, except in 1992.

Part II of Table 2 presents estimates of sales to and purchases of FAJF to and from foreigners. To obtain sales of FAJF to foreigners (42,160 billion yen in 1987), we subtract from their total sales both sales among themselves and their sales to Japan. Data on sales among FAJF are not available. However, intra-group sales of FAJF to local markets and third 
countries, which are a part of sales among FAJF, can be estimated. The old FAJF series for the years 1989 and 1992 give shares of intra-group sales of FAJF (to local markets, to Japan, and to third countries) to total sales of FAJF for each sector. By multiplying each sector's total sales by these shares and adding them across sectors, we obtain proxies for sales among FAJF. Since these shares are available only for 1989 and 1992, the 1989 shares are used for 19871988 and 1990-1991. The other term to be subtracted, Japanese imports shipped by FAJF, may contain a large error, as discussed above.

Purchases of FAJF from foreigners abroad (23,950 billion yen in 1987) are calculated by subtracting from their total purchases both purchases from other FAJF and Japanese exports shipped to FAJF. Data on purchases by FAJF are directly available, which is an advantageous feature of the Japanese statistics compared with the U.S. BEA statistics. The next term, purchases from other FAJF by FAJF, is not directly available. We use intra-group sales of FAJF to local and third countries, estimated above, as a proxy. ${ }^{9}$ The other terms to be subtracted, Japanese exports shipped to FAJF, may contain large estimation errors for the above-mentioned reasons. Our estimation of net sales by FAJF to foreigners is 23,950 billion yen for 1987 .

Part III of Table 2 presents the estimates of net sales of Japanese to JAFF, which were $-5,927$ billion yen in 1987 . Again, the JAFF series published by MITI directly provide data on purchases by JAFF. Sales among JAFF, however, are not available. We thus calculate Japanese sales to JAFF (3,464 billion yen in 1987) by subtracting Japanese imports shipped to JAFF from total purchases by JAFF. Japanese purchases from JAFF $(9,391$ billion yen in 1987) are obtained by subtracting Japanese exports shipped by JAFF from total sales by JAFF. 
By summing up these three components, we obtain estimates of net sales to foreigners by Japanese, for example, 20,116 billion yen in 1987 .

Despite the possible differences from the true figures, our nationality-based account characterizes various key feature of the Japanese economy. First, the asymmetry between FAJF and JAFF is apparent. As often pointed out (see, for example, Lawrence (1993) and Bergsten and Noland (1993, pp. 79-82)), the activities of JAFF are much smaller than those of FAJF. Second, net sales by Japanese to foreigners are consistently larger than the crossborder net sales (exports). This, of course, is due to the larger activities of FAJF than those of JAFF. According to our estimates, nationality-adjusted net sales grew at a considerably faster pace than cross-border net sales between 1988 and $1992 .^{10} \quad$ The strong yen, the savinginvestment balance, the so-called "bubble economy," the competitive edge vis-a-vis the exchange rate, and fear of foreign protectionism seem to have accelerated Japanese outward DFI. Third, compared with the United States, the proportion of cross-border transactions through foreign affiliates is large. Based on our estimates for 1987, U.S. exports and imports through foreign affiliates of U.S. firms (FAUSF) are $25.1 \%$ and $15.2 \%$ of total U.S. exports and imports, while Japanese exports and imports through FAJF are $61.7 \%$ and $42.8 \%$ of total Japanese exports and imports. Although the ratio on the export side for Japan sharply declines to $34.1 \%$ in 1992 , both ratios are still higher than those for the United States. ${ }^{11}$ As we mentioned, our estimates of by-destination sales and by-origin purchasesof FAJF could contain large errors, but we can still infer that Japan depends on its foreign affiliates in export and import transactions much more extensively than the United States does. Activities by FAJF in the commercial sector are particularly important. According to our estimates, Japanese 
exports and imports through commercial FAJF amounted to $48.2 \%$ and $36.0 \%$ of total Japanese exports and imports in 1987. We discuss commercial FAJF further in Section V.

\section{(3) Estimates of value added by FAJF and JAFF}

The same data set as we used in constructing Table 2, can also be utilized to estimate value added by FAJF and JAFF. Since the old FAJF and JAFF series published by MITI directly report total sales and purchases by FAJF and FAFF, value added can be calculated by simply subtracting total purchases from total sales. Strictly speaking, we need to take into consideration such factors as depreciation, indirect taxes, and changes in inventory stock, but data on these variables are not available. Table 3 and Figure 2 present our estimates. The format of the table and the figure follows our companion paper for the United States.

Table 3 also reports ratios of value added by FAJF to value added by all Japaneseowned firms, the latter being defined as Japanese GDP plus value added by FAJF minus value added by JAFF, and ratios of value added by JAFF to the GDP of Japan. ${ }^{12}$ The ratio of value added by FAJF to the value added by all Japanese-owned firms increased during the period, but the figures of $8.33 \%$ and $7.87 \%$ for 1991 and 1992 may be overstated due to an unusually low purchases figure compared with the corresponding sales figure. ${ }^{13}$ We can, however, conclude that Japanese firms have increased the extent of production abroad and have roughly reached the same degree of internationalization of activities as U.S. firms have. As reported in our companion paper, the ratio of value added by FAUSF to that of U.S-owned firms ranges from 5 to $6 \%$. The ratio of value added by JAFF to Japanese GDP, in contrast, is generally only a little larger than $1 \%$. The asymmetry between the behavior of FAJF and JAFF is 
obvious.

The proportion of foreign activities by Japanese firms is often measured by the foreign production ratio, which is defined as the ratio of the value of production of FAJF to total domestic production. The figure for the manufacturing sector in the 1993 fiscal year, for example, is estimated as $6.4 \%$ by MITI $(1994$, p. 46$)$. The value of production, however, includes the value of intermediate inputs and thus is not appropriate for measuring the size of economic activities in Japan and abroad. Our value added method is conceptually better for indicating the proportion of foreign activities of Japanese firms although it may contain considerable measurement errors due to the quality of data.

(4) Comparison of exports and DFI on a value added basis

In other empirical studies, firms' choice between exports and DFI is usually captured by comparing basically incomparable figures, namely, exports and DFI flows. Our value added method makes it possible to compare directly two ways by which firms can sell their products to foreigners abroad: by producing domestically and exporting or by producing abroad and selling there.

Following the companion paper for the United States, we calculate Japanese value added figures in exports of Japanese-owned firms. They are useful in comparing the proportion of Japanese firms' sales activities to foreigners through cross-border transactions and through the activities of FAJF. To obtain the estimates, we subtract exports by FAJF from total cross-border exports and then subtract the import component in the remaining exports. ${ }^{14}$ In Japan, input-output tables are presented in the non-competitive-import form and hence 
directly provide the import inducement coefficient of exports or the direct and indirect import content of exports. This was $10.36 \%$ in 1990 . By using this figure for $1987-1992$, Japanese value added in exports of Japanese-owned firms can be calculated. This amounted to 28,941 billion yen in 1987 , for example. Out of the 28,941 billion yen, 10,501 billion yen is the value added in exports by Japanese firms located in Japan to foreigners abroad. This figure is directly comparable with the 10,384 billion yen of value added in the goods and services sold by FAJF to foreigners. There are two ways for Japanese firms to sell their products to foreigners: by producing in Japan and exporting or producing abroad and selling there. The comparison between 10,501 billion yen and 10,384 billion yen provides a clear idea of the relative importance of these two marketing methods. Compared with the same figures for the United States reported in Baldwin and Kimura (1996), transactions by Japanese foreign affiliates are more important, due mainly to the large ratio of exports by FAJF to total exports. Even after discounting the large estimates of value added by FAJF in 1991 and 1992, transactions by FAJF seem to be becoming more important over time.

Value added in exporting countries by foreign-owned firms is estimated in a similar way. Because input-output tables for the rest of the world are not available, the figure for Japan, $10.36 \%$, is tentatively used. The estimate of value added in exporting countries by foreign-owned firms abroad is 11,154 billion yen in 1987 . Out of this, value added in foreign exports to Japanese in Japan is $\mathbf{8 , 6 2 5}$ billion yen. This figure can be directly compared with 3,727 billion yen, which is the value added in goods and services sold by JAFF to Japanese in Japan. The importance of transactions through JAFF seems to be becoming smaller over time. 


\section{Estimation of sectoral net sales}

(1) Sectoral net sales

In this section, we estimate nationality-based net sales by individual industrial sectors. We believe that they provide a better idea of firms' international competitiveness determined by technological know-how and managerial ability than cross-border net exports do.

A problem arising in sectoral matching of DFI figures and trade statistics is that affiliate data are classified by industries while cross-border trade data are classified by commodities. This difference leads to a serious problem, particularly in the treatment of the commercial sector. We therefore estimate net sales only for the manufacturing sector.

Nationality-adjusted sales for individual sectors are calculated as follows:

Nationality-adjusted sales $=$ Japan's cross-border exports

+ sales by FAJF + purchases by JAFF - Japan's exports shipped to FAJF

- Japan's imports shipped by FAJF - sales to other FAJF by FAJF

- Japan's exports shipped by JAFF - Japan's imports shipped to JAFF.

On the other hand, nationality-adjusted purchases for individual sectors are defined as

Nationality-adjusted purchases $=$ Japan's cross-border imports

+ sales by JAFF + purchases by FAJF - Japan's exports shipped to FAJF

- Japan's imports shipped by FAJF - purchases from other FAJF by FAJF

- Japan's exports shipped by JAFF - Japan's imports shipped to JAFF.

Nationality-adjusted net sales are calculated by subtracting nationality-adjusted purchases from nationality-adjusted sales. We assume that each industry purchases intermediate inputs only from their own industry, since the data of sectoral purchases by industrial origin are not 
available. This is, of course, a strong assumption but should roughly hold for the manufacturing sector. Nationality-adjusted net sales of an individual industrial sector then become equivalent to cross-border net sales (exports) plus value added by FAJF minus value added by JAFF for the sector. By following this estimation procedure, possible estimation errors in by-destination sales and by-origin purchases by FAJF and JAFF are canceled out in the calculation. ${ }^{15}$

Table 4 presents cross-border net sales, nationality-adjusted net sales, and their ratios to the corresponding total sales (of all firms in Japan or of all Japanese-owned firms). To be consistent with the macroeconomic figures, we use sectoral data on the value of output (in producer prices) obtained from the national account statistics as a proxy of the total sales of all firms in Japan. ${ }^{16}$ The figures for aggregate cross-border net sales are slightly different from those for the cross-border merchandise trade balance shown in Table 2, because the former are based on United Nations data reported in U.S. dollars, while the latter are from the Japan Statistical Yearbook reported in yen. The other data are taken directly from the FAJF and JAFF series published by MITI.

For the manufacturing sector as a whole, net sales figures, both cross-border and nationality-adjusted, are positive as expected. However, whereas the ratios of nationalityadjusted net sales to total sales have increased since 1989, those of cross-border ones have not changed much. This suggests that the international competitiveness of Japanese manufacturing firms has increased, while that of firms in territorial Japan has not. We again have to note reservation about the 1991-1992 figures, however. As for sectoral patterns, large positive net sales, both cross-border and nationality-adjusted, are found in general machinery, electrical 
machinery, transport equipment, and precision machinery, and negative net sales are shown for food processing, textiles, chemicals (except nationality-adjusted net sales in 1992), and petroleum and coal products. The ratios of nationality-adjusted net sales to total sales sometimes exhibit significant sudden changes, for example, textiles in 1989 and petroleum and coal products in 1992, even though the ratios of cross-border net sales to total sales do not change appreciably. Such jumps are mainly caused by drastic increases in sectoral value added by FAJF.

(2) Sectoral significance of FAJF and JAFF

The macroeconomic significance of the activities of FAJF and JAFF have already been discussed. The sectoral importance of the activities of FAJF and JAFF can be obtained by using sectoral data on output, value added, and employment in the Japanese national accounts statistics. Table 5 presents shares of FAJF in Japanese-owned firms (firms in Japan minus JAFF plus FAJF) and shares of JAFF in firms in Japan in terms of sales, value added, and employment.

Although there are some irregular up-and-downs partly due to the sampling problem, the figures still provide useful information for analyzing differences in the relative importance of FAJF and JAFF across manufacturing subsectors and across time. The value added shares are particularly useful for comparative purposes. The major findings are as follows: first, the value added share of FAJF in Japanese-owned firms for the total manufacturing sector increased from $3.76 \%$ in 1987 to $8.57 \%$ in 1990 , and then to $10.76 \%$ by 1992 . The importance of the activities of foreign affiliates for Japanese-owned manufacturing firms does not appear 
to be as extensive as for U.S.-owned firms but has been increasing. We again need to discount the figures for 1991 and 1992, however. The share of JAFF in the activities of all firms in Japan has been low and nearly constant. The asymmetry of inward and outward DFI is also apparent at the sectoral level.

Second, industries of comparative advantage for Japan, such as electrical machinery and transport equipment, have rapidly increased the ratio of value added in FAJF to that in Japanese-owned firms. In 1992, the ratios were as high as $17.29 \%$ and $29.66 \%$ for electrical machinery and transport equipment. The value added shares of JAFF to firms in Japan, in contrast, started from a low level in 1987 and still remained low in 1992, e.g., 5.09\% and $0.69 \%$ in these sectors. The value added shares of FAJF to Japanese-owned firms for general machinery and precision machinery show some anomalies in 1992; in that year, value added by FAJF in these industries decreased drastically. We are not sure whether this is due to a small, unstable sample, to industry reclassification of firms, or changes in firms' strategies.

Third, in industries of comparative disadvantage for Japan, such as textiles and chemicals, the shares of FAJF to Japanese-owned firms have also increased. The share of JAFF to firms in Japan also increased in the chemical industry. Large outward and inward DFI characterizes the chemical industry in the case of the United States, and the Japanese chemical industry seems to behave in the same manner.

\section{Commercial FAJF and the presence of general trading companies}

A special feature of foreign affiliates of Japanese firms is the large presence of commercial FAJF in the commercial sector, particularly in the wholesale trade sector. Table 
6 presents the Japan-U.S. comparison of manufacturing and commercial affiliates in 1991 . The table classifies industries both for parent companies and for foreign affiliates. FAJF in the wholesale trade sector have $75 \%$ and $56 \%$ shares in all FAJF in terms of sales and value added, while FAUSF (foreign affiliates of U.S. firms) in the wholesale trade sector (excluding petroleum wholesale trade) have shares of $18 \%$ and $12 \% .{ }^{17}$ Although the figures for FAUSF would become larger by including wholesale petroleum trade, the figures for FAJF are still much larger than those for FAUSF. FAJF in the wholesale trade sector are also characterized by high value added per employee compared with FAUSF.

Table 6 also shows an interesting contrast between figures based on the industry classification of parent companies and those based on the classification of affiliates. In the case of FAUSF, we see that most of FAUSF in the wholesale trade sector have parent companies in non-wholesale-trade sectors. This means that a major function of wholesale FAUSF is undertaking foreign marketing operations for manufacturing parent companies. In contrast, in the case of FAJF, about a half of FAJF in the wholesale trade sector have parent companies in the wholesale trade sector. This suggests that general trading companies (GTCs) play a large role in Japanese international transactions.

A special study conducted by the Japan Foreign Trade Council presents data for sales by the "major branches" of the nine largest Japanese GTCs. ${ }^{18}$ The "major branches" are defined as foreign affiliates of GTCs that have close contacts with the Japanese headquarters and organize local activities. The sample covered 197 affiliates in 37 countries. Table 7 presents the sales figures. Although we have some reservations on the quality of these data, particularly because of double-counting of transactions among the firms, the significance of 
GTCs' activities is apparent. The sales to Japan by the GTC major branches have a $98 \%$ share in those by commercial FAJF in our estimates. The same share in terms of the sales to third countries is $105 \%$. These shares are, of course, subject to estimation errors, but they clearly indicate that the presence of GTCs in international transactions of commercial FAJF is large.

\section{Concluding remarks}

In this paper, we applied our nationality-based net sales and value added framework to Japanese data. Foreign production activities of Japanese firms have been increasingly important, and the nationality-based net sales estimates proved to be useful in analyzing firms international activities. Our value added accounting also provides an integrated framework for analyzing both exports and activities of foreign affiliates and thereby in understanding key characteristics of the Japanese economy.

We found that Japan is special in the following four aspects. First, Japanese-owned firms have become increasingly dependent on the marketing activities of their foreign affiliates (FAJF), rather than depending on cross-border exports by parent firms located in Japan. Second, the asymmetry between inward and outward DFI is apparent in terms of sales, value added, and employment, at both the macroeconomic and sectoral levels. Third, Japanese net sales to foreigners are consistently larger than cross-border net exports of Japan. Fourth, among the activities of FAJF, the importance of commercial FAJF is particularly large, with these commercial affiliates handling a large portion of Japanese exports and imports. Our statistical framework is useful for identifying these characteristics.

To apply our analytical framework more rigorously, a number of statistical 
improvements are required. First, MITI or the Government of Japan must develop an enforceable data collection system for both inward and outward DFI on a proper legal basis. This statistical reform should increase the coverage of the surveys as well as improve the quality of the information on the questionnaires, particularly that on by-destination sales and by-origin purchases of affiliates. In this regard, introducing the new FAJF series has been a major step by MITI in improving data collection. Hopefully, more questions on foreign affiliates will be included in the survey, and the survey will be integrated with the old FAJF series. Second, the extended surveys of the old FAJF series implemented once every three years report ratios of "within-the-same-firm-group" sales and purchases to total sales and purchases, but no data on sales among FAJF or among JAFF are collected, as the U.S. BEA surveys do. Adding questions on sales among affiliates will help apply our method more precisely. Third, we need to develop a proper statistical framework to capture the activities of commercial FAJF. Possible double-counting in the sales to or purchases from Japan or third countries by FAJF must be corrected. In addition, possible double-counting coming from the definition of FAJF must be eliminated. 


\section{References}

Baldwin, Robert E. and Kimura, Fukunari. (1996) "Measuring U.S. International Goods and Services Transactions." (In this volume).

Bergsten, C. Fred and Noland, Marcus. (1993) Reconcilable Differences? United States Japan Economic Conflict. Washington, D.C.: Institute for International Economics.

Economic Planning Agency (EPA), Government of Japan. (1994) Heisei 6-nen ban kokumin keizai keisan nenpou (Annual Report on National Accounts, 1994). Tokyo: Economic Planning Agency, Government of Japan [EPA94].

International Monetary Fund. (1992) International Financial Statistics Yearbook 1992. Washington, D.C.: International Monetary Fund [IMF92].

International Monetary Fund. (1994) International Financial Statistics November 1994. Washington, D.C.: International Monetary Fund [IMF94].

Lawrence, Robert Z. (1993) “Japan's Low Levels of Inward Investment: The Role of Inhibitions on Acquisitions" in Kenneth A. Froot, ed., Foreign Direct Investment. Chicago: The University of Chicago Press.

Lipsey, Robert E.; Blomstrom, Magnus; and Ramstetter, Eric. (1996) "Internationalized Production in World Output." (In this volume).

Mataloni, Jr., Raymond J. (1994) “U.S. Multinational Companies: Operations in 1992." Survey of Current Business (June): 42-62.

Management and Coordination Agency, Government of Japan. (1994) 1990 Input-Output Tables: Explanatory Report. Tokyo: Management and Coordination Agency, 
Government of Japan [IO90].

Ministry of International Trade and Industry, Government of Japan (1990a) Dai 18, $19 \mathrm{kai}$ wagakuni kigyou no kaigai jigyou katsudou (The 18th and 19th Survey of Foreign Affiliates of Japanese Firms). Tokyo: Printing Office, Ministry of Finance, Government of Japan [OLD87/88].

Ministry of International Trade and Industry, Government of Japan. (1990b) Dai 22, 23 kai gaishi-kei kigyou no doukou (The 22nd and 23rd Survey of Japanese Affiliates of Foreign Firms). Tokyo: Printing Office, Ministry of Finance, Government of Japan [AF87/88].

Ministry of International Trade and Industry, Government of Japan (1991a) Dai 4 kai kaigai toushi toukei souran (The 4th Statistics on Japanese Direct Investment Abroad). Tokyo: Printing Office, Ministry of Finance, Government of Japan [OLD89].

Ministry of International Trade and Industry, Government of Japan. (1991b) Dai 24 kai gaishi-kei kigyou no doukou (The 24th Survey of Japanese Affiliates of Foreign Firms). Tokyo: Printing Office, Ministry of Finance, Government of Japan [AF89].

Ministry of International Trade and Industry, Government of Japan (1992a) Dai $21 \mathrm{kai}$ wagakuni kigyou no kaigai jigyou katsudou (The 21st Survey of Foreign Affiliates of Japanese Firms). Tokyo: Printing Office, Ministry of Finance, Government of Japan [OLD90].

Ministry of International Trade and Industry, Government of Japan. (1992b) Dai 25 kai gaishi-kei kigyou no doukou (The 25th Survey of Japanese Affiliates of Foreign Firms). Tokyo: Printing Office, Ministry of Finance, Government of Japan [AF90]. 
Ministry of International Trade and Industry, Government of Japan (1993a) Dai 22 kai wagakuni kigyou no kaigai jigyou katsudou (The 22nd Survey of Foreign Affiliates of Japanese Firms). Tokyo: Printing Office, Ministry of Finance, Government of Japan [OLD91].

Ministry of International Trade and Industry, Government of Japan. (1993b) Dai 26 kai gaishi-kei kigyou no doukou (The 26th Survey of Japanese Affiliates of Foreign Firms). Tokyo: Printing Office, Ministry of Finance, Government of Japan [AF91].

Ministry of International Trade and Industry, Government of Japan (1994a) Dai 5 kai kaigai toushi toukei souran (The 5th Statistics on Japanese Direct Investment Abroad). Tokyo: Printing Office, Ministry of Finance, Government of Japan [OLD92].

Ministry of International Trade and Industry, Government of Japan. (1994b) Dai 27 kai gaishi-kei kigyou no doukou (The 27th Survey of Japanese Affiliates of Foreign Firms). Tokyo: Printing Office, Ministry of Finance, Government of Japan [AF92].

Ministry of International Trade and Industry, Government of Japan. (1994c) White Paper on International Trade: Japan 1994. Tokyo: Japan External Trade Organization.

Ministry of International Trade and Industry, Government of Japan (1994d) Results of the Basic Survey of Business Structure and Activity, 1992: Volume 3 Report by Subsidiary Companies. Tokyo: Shadan Houjin Tsuusan Toukei Kyoukai [NEW91].

Statistical Bureau, Management and Coordination Agency, Government of Japan. (1990) Japan Statistical Yearbook 1990. Tokyo: Printing Office, Ministry of Finance, Government of Japan [JSY90].

Statistical Bureau, Management and Coordination Agency, Government of Japan. (1992) 
Japan Statistical Yearbook 1992. Tokyo: Printing Office, Ministry of Finance, Government of Japan [JSY92].

Statistical Bureau, Management and Coordination Agency, Government of Japan. (1994) Japan Statistical Yearbook 1993/94. Tokyo: Printing Office, Ministry of Finance, Government of Japan [JSY93/94].

Statistical Bureau, Management and Coordination Agency, Government of Japan. (1995) Japan Statistical Yearbook 1995. Tokyo: Printing Office, Ministry of Finance, Government of Japan [JSY95].

United Nations. (1992) 1990 International Trade Statistics Yearbook: Volume 1 Trade by Country. New York: United Nations [UN90].

United Nations. (1993) 1992 International Trade Statistics Yearbook: Volume I Trade by Country. New York: United Nations [UN92].

U.S. Department of Commerce. (1994) U.S. Direct Investment Abroad: Operations of U.S. Parent Companies and Their Foreign Affiliates. Revised 1991 Estimates. Washington, D.C.: U.S. Government Printing Office [FAUSF91]. 


\section{ENDNOTES}

1. The BOP framework determines the residency of individuals and firms by whether or not they reside in a country for one year or more (in the IMF version of the BOP manual; in the Japanese version, more than two years for Japanese abroad and more than six months for foreigners in Japan). This means that, for example, a U.S. affiliate of a Japanese firm established more than a year ago is treated as American. Hence, merchandise and services trade is basically captured as transactions between economic agents in different geographical locations, rather than between economic agents with different nationalities.

2. One of the problems of this list of enterprises is that there is no systematic procedure for updating the list. It therefore may include enterprises or foreign affiliates which once existed but are not in business anymore.

3. BEA (Bureau of Economic Analysis, U.S. Department of Commerce) tried to collect purchases data in the past, but it deleted the question from the questionnaire because it could not collect reliable figures.

4. The new FAJF series can be used for checking the accuracy of the old FAJF series. For the 1991 financial year data, for example, one may question the quality of sales and purchases data reported by the old FAJF series, which differ widely from those in the new FAJ F series. MITI is currently trying to reformulate the formats of the old and new FAJF series into an integrated framework.

5. Again, one of the problems is that there is no systmatic procedure to update the list of JAFF. MITI is currently trying to integrate the JAFF series and domestic establishment surveys. The OECD is promoting this approach with a number of countries, including the UK and France.

6. The definition of FAJF in the new FAJF series is "majority-owned." 
7. Possible errors listed in this paragraph do not affect our estimation of Japanese net sales to foreigners shown in Part IV of Table 2. As Lois Steckler of the Board of Governors points out in personal correspondence, Japanese net sales to foreigners are conceptually equivalent to cross-border net exports plus FAJF's value added (sales minus purchases) minus JAFF's value added (sales minus purchases). The possible error terms are canceled out in the calculation of Japanese net sales to foreigners.

8. These possible errors do not affect our estimation of Japanese net sales to foreigners.

9. Intra-group purchases from local and third countries can be estimated in a symmetric manner. However, the estimates differ from intra-group sales to local and third countries, though these must be equivalent in principle.

10. The estimate of nationality-adjusted sales of 1988 is particularly small, while those of 1991 and 1992 look very large. This fluctuation is mainly due to changes in the value added by FAJF, which may contain large estimation errors. We, however, can at least conclude that the activities of JAFF expanded until 1990.

11. The decline in the estimated ratio on the export side for 1992 may be due to the understatement of purchases by FAJF.

12. Value added by Japanese-owned firms as well as Japanese GDP includes production that takes place outside firms, such as in the government and household sectors.

13. As mentioned in Footnote 5 of Table 1, the 1991 data of sales and purchases provided by the new FAJF series suggest much smaller value added by FAJF. The ratios of value added by FAJF to sales under the old FAJF series in Table 3 also look too large for 1991 and 1992. This may be due to the small number of FAJF providing purchases figures, though this cannot be proven from 
published documents.

14. Precisely speaking, we must consider the JAFF component in these exports to avoid doublecounting, but the data are not available.

15. The sector matching list between our industry (commodity) classification and SITC Rev. 2 is available upon request.

16. Alternatively, we can use sales data of "Financial Statements of Corporations by Industry" by the Ministry of Finance or value of shipments data of "Census of Manufactures" collected by MITI, though figures widely differ mainly due to the difference in coverage and the definition of firms or establishments.

17. It should be noted that FAJF do not include affiliates (or parent companies) in the finance, insurance, and real estate sectors, while FAUSF do include affiliates (or parent companies) in the finance (excluding banking), insurance, and real estate sectors. We should also take into account that affiliates in the service sector have a larger share in the case of FAUSF than in the case of FAJF. 18. The nine largest Japanese GTCs are C.Itoh, Mitsui, Sumitomo, Marubeni, Mitsubishi, Nissho Iwai, Tomen, Nichimen, and Kanematsu Gosho. The study by the Japan Foreign Trade Council covers only the financial years 1983 and 1987. 


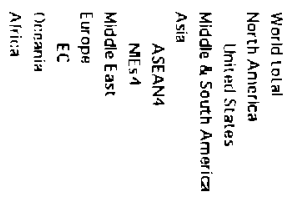

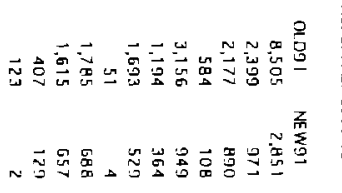

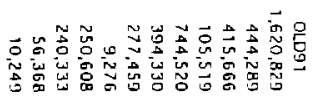

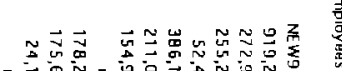

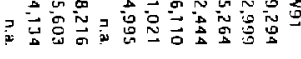

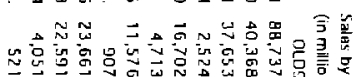

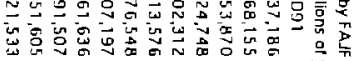

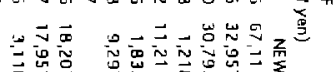

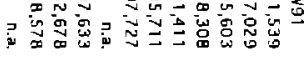

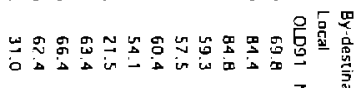

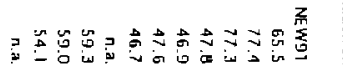

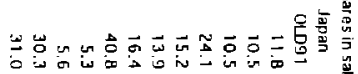

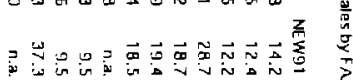

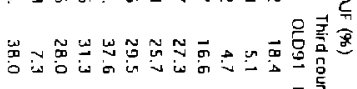

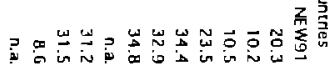

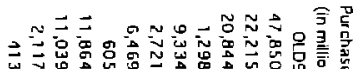

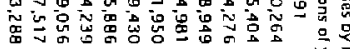

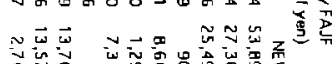

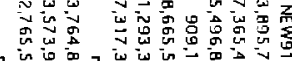

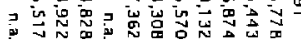

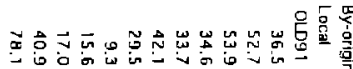

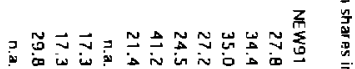

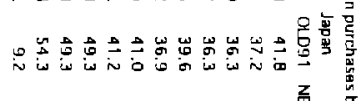

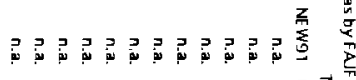

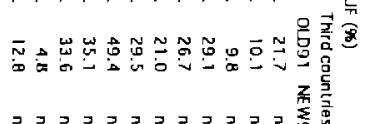

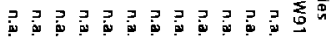

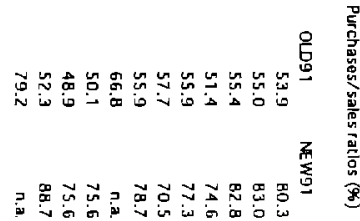

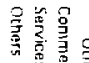<smiles>Cc1ccc(C)cc1</smiles>

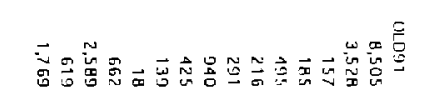

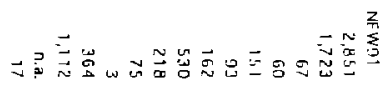

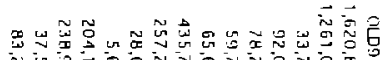

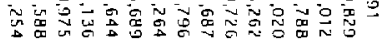

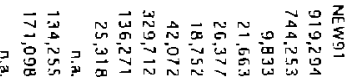

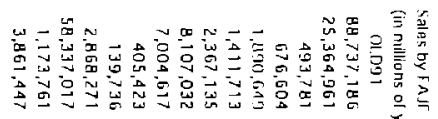

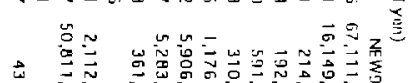

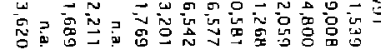

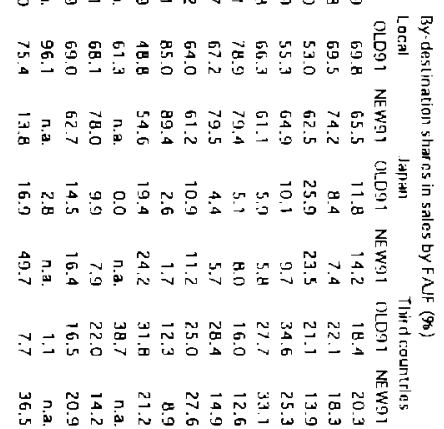

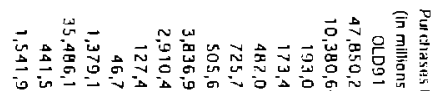

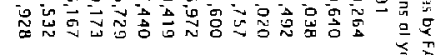

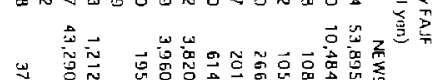

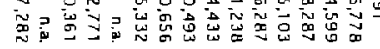

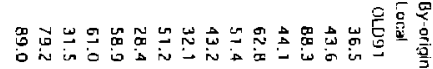

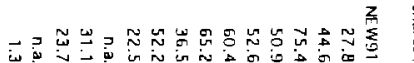

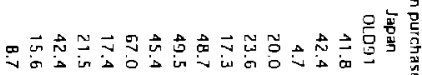

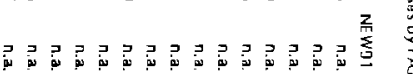

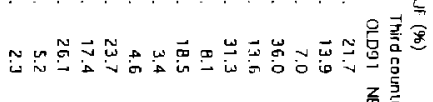

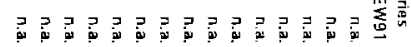

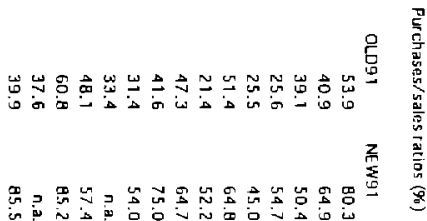


Table 2 Net Sales by Japanese to Foreigners, 1987-1992

(in millions of yen)

Transaction

I. Cross-border sales to and purchases from foreigners by Japanese Exports to foreigners

+ Japanese exports (merchandise only)

- Japanese exports shipped to FAJF

- Japanese exports shipped by JAFF

Total

Imports from foreigners

+ Japanese imports (merchandise only)

- Japanese imports shipped by FAJF

- Japanese imports shipped to JAFF

Total

Net cross-border sales to foreigners

il. Sales to and purchases from foreigners by FAJF

Sales by FAJF

+ Sales by FAJF

- Sales to other FA.JF

- Japanese imports shipped by FAJF

Total

Local purchases abroad by FAJF

+ Purchases by FAJF

- Purchases from other FAJF

- Japanese exports shipped to FAJF

Total

Net sales to foreigners by FAJF

III. Japanese sales to and purchases from JAFF

Japanese sales to J AFF

+ Purchases by JAFF

- Sales among JAFF

- Japanese imports shipped to JAFF

Total

Japanese purchases from JAFF

+ Sales by JAFF

- Sales among JAFF

- Japanese exports shipped by JAFF Toral

Net sales to JAFF

IV. Net sales by Japanese to foreigners

(Figures in parentheses are in millions of dollars.)

Reference

Cross-border merchandise trade balance

(Figures in parentheses are in millions of dollars.)

Exchange rates ( $r$; yen per dollar)
Amount

1987

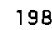

1989

1990

1991

1992

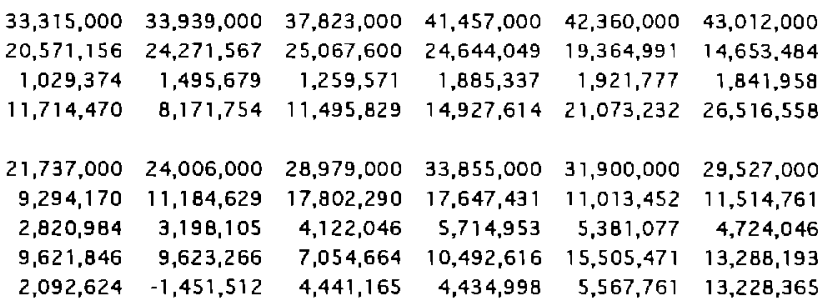

$\begin{array}{llllll}54,808,975 & 68,426,994 & 93,177,600 & 99,806,407 & 88,737,186 & 79,007,218\end{array}$ $\begin{array}{llllll}\mathbf{3 , 3 5 4 , 4 5 7} & 4,795,450 & 6,228,815 & 7,800,237 & 6,570,591 & 8,455,537\end{array}$

$\begin{array}{llllll}9,294,170 & 11,184,629 & 17,802,290 & 17,647,431 & 11,013,452 & 11,514,761\end{array}$

$\begin{array}{lllllll}42,160,348 & 52,446,915 & 69,146,495 & 74,358,739 & 71,153,143 & 59,036,921\end{array}$

$\begin{array}{llllll}42,135,754 & 57,987,023 & 77,139,161 & 73,880,197 & 47,850,264 & 39,660,435\end{array}$ $\begin{array}{rrrrrr}3,354,457 & 4,795,450 & 6,228,815 & 7,800,237 & 6,570,591 & 8,455,537\end{array}$ $20,571,156 \quad 24,271,567 \quad 25,067,600 \quad 24,644,049 \quad 19,364,991 \quad 14,653,484$

$18,210,141 \quad 28,920,006 \quad 45,842,746 \quad 41,435,911 \quad 21,914,682 \quad 16,551,414$

$\begin{array}{llllll}23,950,207 & 23,526,909 & 23,303,749 & 32,922,828 & 49,238,461 & 42,485,506\end{array}$

$\begin{array}{rrrrrr}6,284,978 & 7,665,564 & 9,247,364 & 12,032,837 & 12,060,981 & 11,275,793 \\ \text { n.a. } & \text { n.a. } & \text { n.a. } & \text { n.a. } & \text { n.a. } & \text { n.a. } \\ 2,820,984 & 3,198,105 & 4,122,046 & 5,714,953 & 5,381,077 & 4,724,046 \\ 3,463,994 & 4,467,459 & 5,125,318 & 6,317,884 & 6,679,904 & 6,551,747 \\ & & & & & \\ 10,420,519 & 12,292,986 & 14,003,962 & 16,810,563 & 17,792,870 & 16,300,170 \\ \text { n.a. } & \text { n.a. } & \text { n.a. } & \text { n.a. } & \text { n.a. } & \text { n.a. } \\ 1,029,374 & 1,495,679 & 1,259,571 & 1,885,337 & 1,921,777 & 1,841,958 \\ 9,391,145 & 10,797,307 & 12,744,391 & 14,925,226 & 15,871,093 & 14,458,212 \\ -5,927,151 & -6,329,848 & -7,619,073 & -8,607,342 & -9,191,189 & -7.906,465 \\ & & & & & \\ 20,115,680 & 15,745,549 & 20,125,841 & 28,750,484 & 45,615,033 & 47,807,406 \\ (139,074) & (122,868) & (145,882) & (198,567) & (338,617) & (377,477) \\ & & & & & \\ 11,578,000 & 9,933,000 & 8,844,000 & 7,602,000 & 10,460,000 & 13,485,000 \\ (80,047) & (77,511) & (64,106) & (52,504) & (77,648) & (106,475) \\ 144.64 & 128.15 & 137.96 & 144.79 & 134.71 & 126.65\end{array}$

FAJF: Foreign affiliates of Japanese firms abroad, which include affiliates in which Japanese have more than 10\% share and affiliates in which Japanese majority-owned affiliates have more than $50 \%$ share. Only the parent firms with the largest share report the figures. Only affiliates whose parent companies are in industries other than finance, insurance, and real estates are covered.

Coverages of affiliates data (In terms of number of affiliates) for $1987-1992$ are $79.4 \%, 78.8 \%, 72.3 \%, 78.2 \%, 78.5 \%$, and $65.5 \%$.

JAFF: Majority-owned (with more than one-third shares from $1991 \mathrm{~F} / \mathrm{Y}$ ) Japanese affiliates of foreign fims in Japan, which report their direct investment to MITI and have foreign participation in management. Coverages of affiliates data (in terms of number of affiliates) for 1987-1992 are $50.1 \%, 52.3 \%$, $51.8 \%, 51.8 \%, 51.9 \%$, and $53.7 \%$

Years: Japanese exports and imports are on the calendar-year basis while data for FAJF and JAFF are on the financial-year basis. 
Attachment to Table 2: Estimation Procedure and Data Sources

(Figures in parentheses are for 1987, 88, 89, 90, 91 and 92, respectively; in millions of yen.)

Japanese exports --- Merchandise exports only. JSY90 (p. 338), 92 (p. 338), 95 (p. 417) (33,315,000; $33,939,000 ; 37,823,000 ; 41,457,000 ; 42,360,000 ; 43,012,000)$.

Japanese exports shipped to FAJF --- One of the shortfalls of the old FAJF series is that firms in the sample report total purchases while many of them fail to report the by-origin disaggregation. For example, out of total purchases in $1987(42,135,754)$, only $38.4 \%(16,189,035)$ are disaggregated into local purchases $(5,880,385)$, purchases from Japan $(7,721,739)$, and purchases from third countries $(2,586,911)$. We therefore estimate Japanese exports shipped to FAJF as the sum of sectoral estimates, each of which is derived from multiplying total purchases of the sector by the share of purchases from Japan of the sector (calculated from the limited sample). OLD87/88 (pp. 94-95, 202-203), 89 (pp. 222-223), 90 (pp. 104-105), 91 (pp. 100-101), 92 (pp. $210-211)(20,571,156 ; 24,271,567 ; 25,067,600 ; 24,644,049 ; 19,364,991 ; 14,653,484)$.

Japanese exports shipped by JAFF --- AF87/88 (pp. 71, 225), 89 (p. 73), 90 (p. 77), 91 (p. 75), 92 (p. 79) $(1,029,374 ; 1,495,679 ; 1,259,571 ; 1,885,337 ; 1,921,777 ; 1,841,958)$.

Japanese imports --- Merchandise imports only. JSY90 (p. 338), 92 (p. 338), 95 (p. 417) (21,737,000; $24,006,000 ; 28,979,000 ; 33,855,000 ; 31,900,000 ; 29,527,000)$.

Japanese imports shipped by FAJF --- As in Japanese exports shipped to FAJF, firms in the sample report total sales while many of them fail to report the by-destination disaggregation. For example, out of total sales in $1987(54,808,975)$, only $42.2 \%(23,144,497)$ are disaggtegated into local sales $(15,388,102)$, sales to Japan $(3,770,459)$, and sales to third countries $(3,985,936)$. We therefore estimate Japanese imports shipped by FAJF as the sum of sectoral estimates, each of which is derived from multiplying total sales of the sector by the share of sales to Japan of the sector (calculated from the limited sample). OLD87/88 (pp. 82-83, 190-191), 89 (pp. 210-211), 90 (pp. 88-89), 91 (pp. 88-89), 92 (pp. 198-199) (9,294,170; 11,184,629; 17,802,290; $17,647,431 ; 11,013,452 ; 11,514,761)$.

Japanese imports shipped to JAFF --- AF87/88 (pp. 105, 239), 89 (p. 107), 90 (p. 111), 91 (p. 109), 92 (p. 113) $(2,820,984 ; 3,198,105 ; 4,122,046 ; 5,714,953 ; 5,381,077 ; 4,724,046)$.

Sales by FAJF -.- OLD87/88 (pp. 83, 191), 89 (p. 211), 90 (p. 89), 91 (p. 89), 92 (p. 199) $(54,808,975$; $68,426,994 ; 93,177,600 ; 99,806,407 ; 88,737,186 ; 79,007,218)$.

Sales to other FAJF --- Although the data of sales among FAJF are not available, intra-firm transaction between affiliates can be estimated. For 1989, by using the same method as in estimating Japanese imports from $F A J F$, we first estimate local sales and sales to third countries of each sector. Then, by multiplying ratios of intra-group sales in local sales and sales to third countries of each sector, we can estimate intra-firm trade of the sector. The sum of sectoral estimates provides a proxy of sales to other FAJF. For 1987, 88, 90, and 91, ratios of intra-group sales in 1989 are used OLD87/88 (pp. 82-83, 190-191), 89 (pp. 210-211, 229), 90 (p. 88-89), 91 (pp. 88-89), 92 (pp. 198-199, 217) $(3,354,457 ; 4,795,450 ; 6,228,815 ; 7,800,237 ; 6,570,591 ; 8,455,537$ ).

Purchases by FAJF --- OLD87/88 (pp. 95, 203), 89 (p. 223), 90 (p. 105), 91 (p. 101), 92 (p. 211) $(42,135,754 ; 57,987,023 ; 77,139,161 ; 73,880,197 ; 47,850,264 ; 39,660,435)$

Purchases from other FAJF --- The data of purchases among FAJF are not available. As a proxy, we use sales to other FAJF estimated above.

Purchases by JAFF --. AF87/88 (pp. 105, 239), 89 (p. 107), 90 (p. 111), 91 (p. 109), 92 (p. 113) $(6,284,978 ; 7,665,564 ; 9,247,364 ; 12,032,837 ; 12,060,981 ; 11,275,793)$.

Sales among JAFF --- Not available.

Sales by JAFF --- AF87/88 (pp. 71, 225), 89 (p. 73), 90 (p. 77), 91 (p. 75), 92 (p. 79) (10,420,519; $12,292,986 ; 14,003,962 ; 16,810,563 ; 17,792,870 ; 16,300,170)$.

Exchange rates -.- Yen per dollar (If series). IMF92 (p. 437), 94 (p. 316). (144.64; 128.15; 137.96; $144.79 ; 134.71 ; 126.65)$ 
Table 3 Value Added by FAJF and JAFF, 1987-1992 (in millions of yen)

Transaction

1. Value added by FAJF

+ Sales by FAufF

- Local purchases abroad by FAJF

- Japanese exports shipped to FAJJF

- Purchases from other FAJJ

Total

in goods and services sold to:

Japanese

Foreigners

Received by:

Japanese

Foreigners

Value added / sales ratio (\%)

II. Japanese value added in exports of Japanese-owned firms In export to FAJJ

In exports to foreigners

III. Value added by JAFF

+ Sales by JAFF

- Purchases within Japan by JAFF

- Japanese imports shipped to JAFF

Total

In goods and services sold to:

Japanese

Foreigners

Received by:

Japanese

Foreigners

Value added / sales ratio (\%)

IV. Value added in exporting country by foreign-owned firms

In exports to Japanese

In exports to JAFF
Purchases from other JAFF

\begin{tabular}{|c|c|c|c|c|c|}
\hline \multicolumn{6}{|l|}{ Amount } \\
\hline 1967 & 1988 & 1989 & 1990 & 1991 & 1992 \\
\hline $54,808,975$ & $68,426,994$ & $93,177,600$ & $99,806,407$ & $86,737,186$ & $79,007,218$ \\
\hline $18,210,141$ & $28,920,006$ & $45,842,746$ & $41,435,911$ & $21,914,682$ & $16,551,414$ \\
\hline $20,571,156$ & $24,271,567$ & $25,067,600$ & $24.644,049$ & $19,364,991$ & $14,653,484$ \\
\hline $3,354,457$ & $4,795,450$ & $6,228,815$ & $7,800,237$ & $6,570,591$ & $8,455,537$ \\
\hline $12,673,221$ & $10,439,971$ & $16,038,439$ & $25,926,210$ & $40,8 \in 6,922$ & $39,346,783$ \\
\hline $2,289,149$ & $1,835,052$ & $3,283,7 \in 3$ & $4,972,830$ & $5,480,404$ & $6,421,800$ \\
\hline $10,384,072$ & $8,604,919$ & $12,754,656$ & $20,953,380$ & $35,406,518$ & $32,924,983$ \\
\hline n.a. & n.a. & п.а. & n.a. & п.a. & п.a. \\
\hline n.a. & n.a. & n.a. & na. & п. $\mathbf{a}$. & п.а. \\
\hline 23.12 & 15.26 & 17.21 & 25.98 & 46.06 & 49.80 \\
\hline $28,940,035$ & $29,0 \mathrm{~B} 2,193$ & $32,775,45 \theta$ & $35,472,039$ & $36,904,826$ & $36,248,823$ \\
\hline $18,439,984$ & $21,757,033$ & $22,470,597$ & $22,090,926$ & $17,672,923$ & $12,901,895$ \\
\hline $10,500,651$ & $7,325,160$ & $10,304,661$ & $13,381,113$ & $19,231,902$ & $23,346,92 \mathrm{~B}$ \\
\hline $10,420,519$ & $12,292,986$ & $14,003,962$ & $16,810,563$ & $17,792,670$ & $16,300,170$ \\
\hline $3,463,994$ & $4,467,459$ & $5,125,318$ & $6,317,884$ & $6,679,904$ & $6,551,747$ \\
\hline $2,820,984$ & $3,198,105$ & $4,122,046$ & $5,714,953$ & $5,381,077$ & $4,724,046$ \\
\hline $\begin{array}{r}\text { n.a. } \\
\text {. }\end{array}$ & $\begin{array}{r}\text { ח.a. } \\
\text { ras }\end{array}$ & $\begin{array}{r}\text { n.a. } \\
\text {. }\end{array}$ & n.a. & $\begin{array}{r}\text { n.a. } \\
-\end{array}$ & n.a \\
\hline $4,135,541$ & $4,6<7,4<2$ & $4,756,596$ & $4,871,8<6$ & $3,131,609$ & $5,024,377$ \\
\hline $3,727,018$ & $4,064,407$ & $4,328,771$ & $4,241,895$ & $5,112,798$ & $4,456,610$ \\
\hline 408,523 & 563,015 & 427,827 & 535,831 & 619,091 & 567.767 \\
\hline п.a. & n.a. & n,a. & п.а. & n.a. & n.a. \\
\hline п.а. & n.a. & п.a. & n.a. & n.a. & n.a. \\
\hline 39.69 & 37.64 & 33.97 & 28.42 & 32.21 & 30.82 \\
\hline $11,153,753$ & $11,493,077$ & $10,018,803$ & $14,528,465$ & $18,722,702$ & $16,146,171$ \\
\hline & 6,296 & $6,323,801$ & $9,405,581$ & $13,899,104$ & $11,911,536$ \\
\hline $2,528,730$ & $2,866,781$ & $3,695,002$ & $5,122,884$ & $4,823,597$ & $4,234,635$ \\
\hline
\end{tabular}

Reference:

Gross domestic product of Japan

Ratio of value added of FAJF to that of Japanese-owned firms (\%)

Ratio of value added of JAFF to Japanese GDP (\%) $\begin{array}{lllllll}353,989,000 & 376,889,000 & 402,311,000 & 432,862,000 & 455,862,000 & 465,437,000\end{array}$

$\begin{array}{rrrrrr}3.50 & 2.73 & 3.88 & 5.71 & 8.33 & 7.87 \\ 1.17 & 1.23 & 1.18 & 1.10 & 1.26 & 1.08\end{array}$

[Value added of Japanese-owned firms] = [GDP of Japan] + [value added of FAJF] - [value added of JAFF]

All the data are in financial years (April-March).

Figures in II and $\mathrm{N}$ are estimated by using the import inducement coefficient of export (10.36\%) obtained from logo

(pp. 321, 386). See the text in the detai.

Data sources

GDP of Japan: J5Y92, P. 555; JSY95, p. 142. See Attachment to Table 2 for other data. 


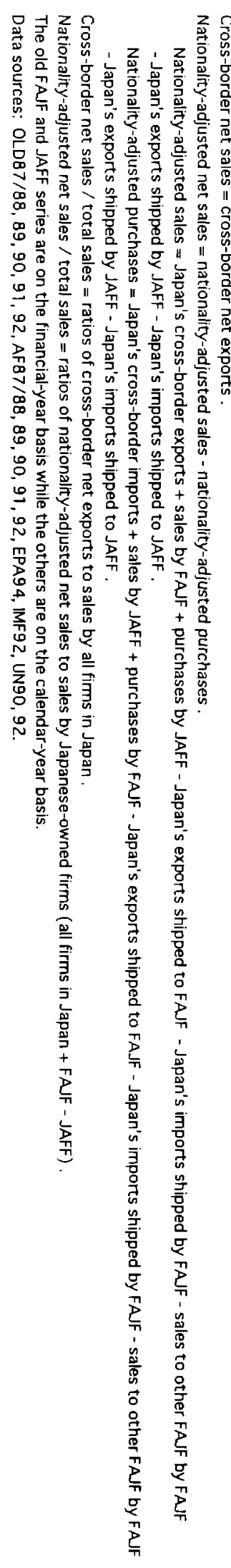

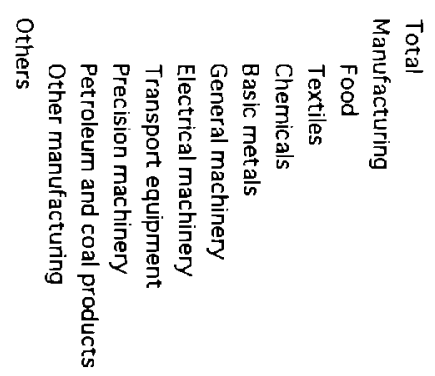

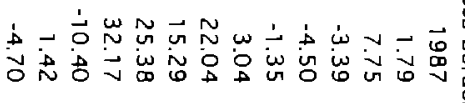

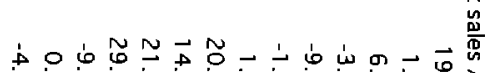

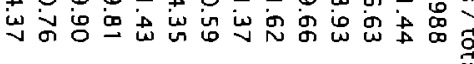

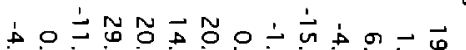

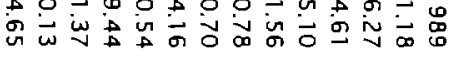

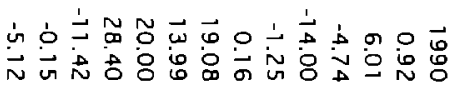

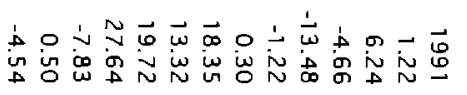

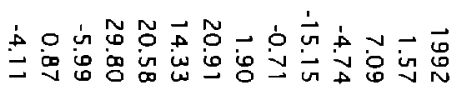

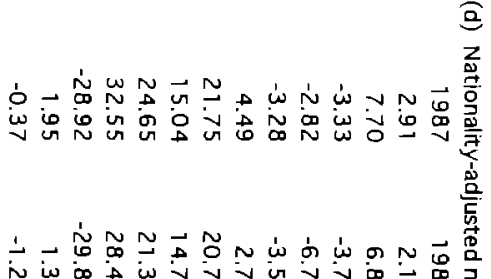

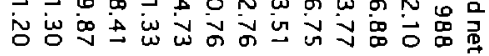

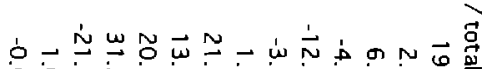

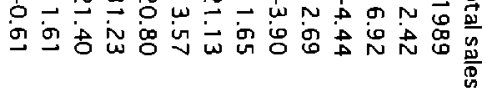

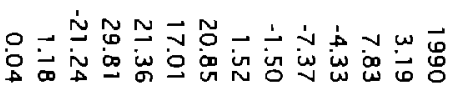

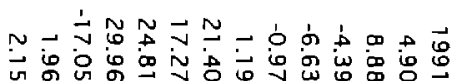

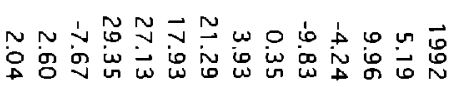

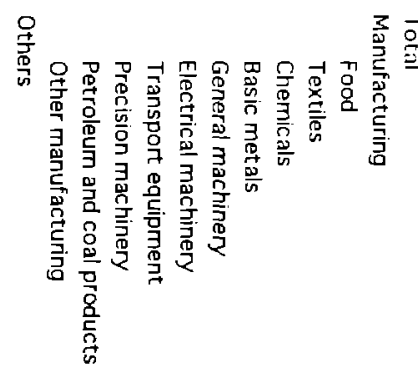

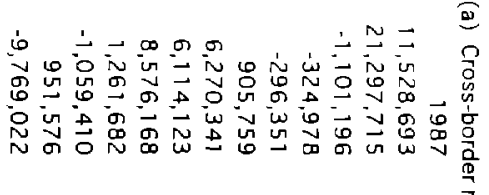

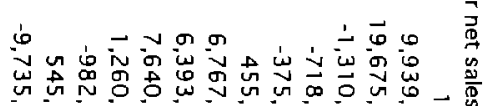

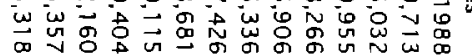

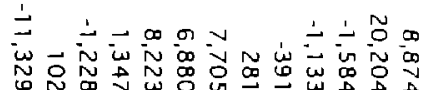

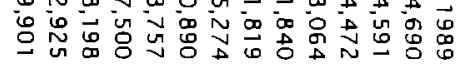

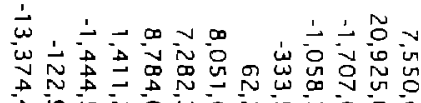

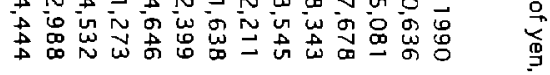

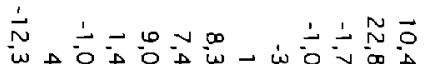

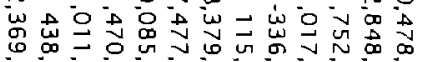

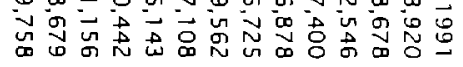

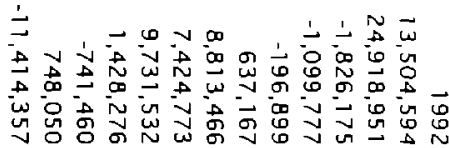

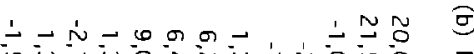

in

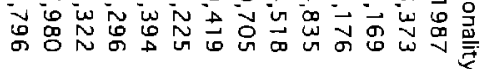

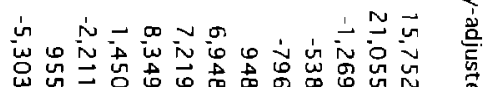

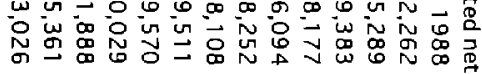

$\dot{\omega}-\dot{\bar{y}}-0)$

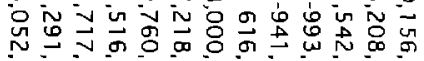

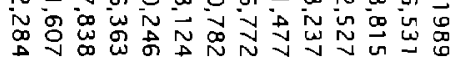

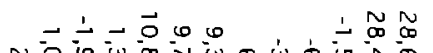

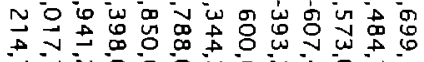

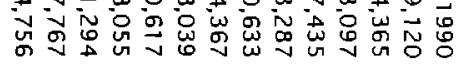

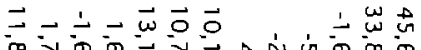

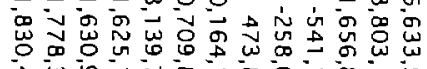

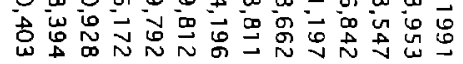

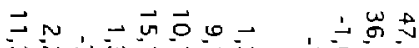

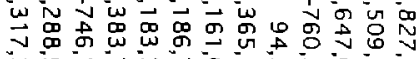

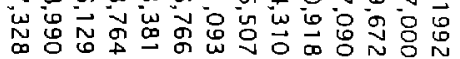


Table 5 Sales, Value Added, and Employment Shares of FAJF and JAFF (\%)

(a) Sales

$\begin{array}{lrrrrrr} & 1987 & 1986 & 1989 & 1990 & 1991 & 1992 \\ \text { Total } & 7.39 & 8.52 & 10.47 & 10.40 & 8.91 & 7.99 \\ \text { Manufacturing } & 4.66 & 5.76 & 6.64 & 7.21 & 6.66 & 6.85 \\ \quad \text { Food } & 0.84 & 1.35 & 1.49 & 1.37 & 1.31 & 1.43 \\ \text { Textiles } & 5.37 & 6.90 & 4.32 & 8.63 & 8.29 & 6.53 \\ \text { Chemicals } & 4.53 & 5.30 & 5.37 & 6.93 & 7.07 & 6.26 \\ \text { Basic metals } & 3.55 & 4.29 & 4.23 & 4.05 & 3.55 & 4.46 \\ \text { General machinery } & 3.03 & 3.30 & 2.95 & 7.10 & 4.98 & 2.86 \\ \text { Electrical machinery } & 10.97 & 13.07 & 12.74 & 13.83 & 13.07 & 12.88 \\ \text { Transport equipment } & 8.72 & 9.66 & 15.40 & 13.74 & 13.23 & 15.97 \\ \quad \text { Precision machinery } & 5.22 & 20.78 & 9.23 & 9.05 & 7.47 & 6.42 \\ \quad \text { Petroleum and coal products } & 0.96 & 0.22 & 0.16 & 0.26 & 1.46 & 6.57 \\ \text { Other manufacturing } & 1.80 & 2.15 & 3.68 & 3.48 & 3.16 & 2.71 \\ \text { Commerce } & 37.22 & 40.57 & 47.21 & \mathbf{4 6 . 5 9} & 41.07 & 36.02 \\ \text { Services } & 0.28 & 0.40 & 0.44 & 0.70 & 0.88 & 0.88 \\ \text { Others } & 0.62 & 0.82 & 1.44 & 1.11 & 1.14 & 1.12\end{array}$

(b) Value added

$\begin{array}{lrrrrrr} & 1987 & 1988 & 1989 & 1990 & 1991 & 1992 \\ \text { Total } & 3.54 & 2.75 & 3.92 & 5.79 & 8.40 & 7.94 \\ \text { Manufacturing } & 3.76 & 4.70 & 5.84 & 8.57 & 10.53 & 10.76 \\ \quad \text { Food } & 0.99 & 1.32 & 1.31 & 1.98 & 2.14 & 2.10 \\ \text { Textiles } & 4.30 & 6.61 & 6.06 & 16.54 & 17.54 & 12.08 \\ \text { Chemicals } & 3.51 & 4.46 & 5.39 & 9.64 & 13.57 & 11.18 \\ \text { Basic metals } & 6.33 & 6.44 & 4.63 & 7.55 & 6.63 & 10.47 \\ \text { General machinery } & 2.21 & 2.21 & 2.78 & 8.08 & 9.75 & 3.19 \\ \text { Electrical machinery } & \mathbf{8 . 8 4} & 10.96 & 11.05 & 17.25 & 18.03 & 17.29 \\ \text { Transport equipment } & 5.30 & 6.92 & 12.21 & 14.60 & 24.30 & 29.66 \\ \text { Precisian machinery } & 5.68 & 13.41 & 11.12 & 12.71 & 12.13 & 6.38 \\ \text { Petroleum and coal products } & 0.52 & 0.13 & 0.06 & 0.21 & 2.09 & 11.98 \\ \text { Other manufacturirg } & 1.80 & 2.02 & 4.34 & 3.69 & 3.89 & 4.46 \\ \text { Commerce } & 15.05 & 8.96 & 13.83 & 17.75 & 28.83 & 26.71 \\ \text { Services } & 0.22 & 0.27 & 0.35 & 0.90 & 1.01 & 1.22 \\ \text { Others } & 0.55 & 0.34 & 0.58 & 1.36 & 1.20 & 1.04\end{array}$

(c) Employment

$\begin{array}{lrrrrrr}\text { Total } & 1.84 & 2.05 & 1.76 & 2.30 & 2.36 & 2.03 \\ \text { Manufacturing } & 5.86 & 6.68 & 5.80 & 7.49 & 7.39 & 6.61 \\ \quad \text { Food } & 1.56 & 1.91 & 1.81 & 2.03 & 2.03 & 1.84 \\ \text { Textiles } & 7.37 & \mathbf{8 . 3 4} & 4.68 & 7.36 & 7.61 & 7.37 \\ \quad \text { Chemicals } & 11.37 & 12.26 & 11.03 & 14.00 & 14.86 & 13.18 \\ \text { Basic metals } & 10.47 & 12.31 & 11.25 & 9.62 & 8.48 & 8.53 \\ \quad \text { General machinery } & 3.40 & 3.78 & 3.15 & 4.85 & 3.51 & 2.67 \\ \text { Electrical machinery } & 12.68 & 13.82 & 11.45 & 14.86 & 14.81 & 13.55 \\ \quad \text { Transport equipment } & 9.29 & 11.63 & 9.48 & 13.47 & 14.32 & 13.30 \\ \quad \text { Precision machinery } & 5.91 & 10.63 & 6.39 & 8.55 & 7.82 & 3.66 \\ \quad \text { Petraleum and coal products } & 4.75 & 12.05 & 0.82 & 13.29 & 13.62 & 2.05 \\ \quad \text { Other manufacturing } & 2.17 & 2.20 & 3.11 & 3.57 & 3.43 & 2.99 \\ \text { Commerce } & 1.53 & 1.52 & 1.16 & 1.50 & 1.99 & 1.34 \\ \text { Services } & 0.18 & 0.17 & 0.22 & 0.34 & 0.26 & 0.32 \\ \text { Others } & 0.29 & 0.30 & 0.28 & 0.33 & 0.33 & 0.30\end{array}$

Share of JAFF in firms in Japan

$\begin{array}{llllll}1987 & 1988 & 1989 & 1990 & 1991 & 1992\end{array}$

$\begin{array}{llllll}1.50 & 1.65 & 1.73 & 1.92 & 1.92 & 1.76\end{array}$

$\begin{array}{llllll}2.68 & 2.76 & 2.86 & 3.08 & 2.90 & 2.88\end{array}$

$\begin{array}{llllll}0.64 & 0.61 & 0.56 & 0.57 & 0.81 & 0.56\end{array}$

$\begin{array}{llllll}0.18 & 0.12 & 0.18 & 0.34 & 0.86 & 0.37\end{array}$

$\begin{array}{llllll}6.40 & 7.76 & 9.28 & 8.87 & 10.28 & 8.87\end{array}$

$\begin{array}{llllll}0.25 & 0.92 & 0.84 & 0.87 & 0.99 & 1.21\end{array}$

$\begin{array}{llllll}2.70 & 1.55 & 1.25 & 1.38 & 1.20 & 0.83\end{array}$

$\begin{array}{llllll}3.96 & 4.36 & 4.47 & 4.72 & 4.00 & 4.44\end{array}$

$\begin{array}{llllll}0.59 & 0.80 & 0.86 & 0.25 & 0.26 & 0.55\end{array}$

$\begin{array}{llllll}3.31 & 4.37 & 3.68 & 14.15 & 5.65 & 7.93\end{array}$

$\begin{array}{llllll}26.46 & 25.53 & 25.80 & 27.93 & 27.01 & 26.53\end{array}$

$\begin{array}{llllll}0.42 & 0.57 & 0.57 & 0.46 & 0.37 & 0.53\end{array}$

$\begin{array}{llllll}4.15 & 5.13 & 5.80 & 6.64 & 7.29 & 6.13\end{array}$

$\begin{array}{llllll}0.04 & 0.07 & 0.04 & 0.09 & 0.31 & 0.26\end{array}$

$\begin{array}{llllll}0.05 & 0.08 & 0.06 & 0.11 & 0.05 & 0.04\end{array}$

Share of JAFF in firms in Japan

$\begin{array}{rrrrrr}1987 & 1988 & 1989 & 1990 & 1991 & 1992 \\ 1.18 & 1.24 & 1.19 & 1.12 & 1.27 & 1.09 \\ 3.48 & 3.47 & 3.37 & 2.98 & 3.07 & 2.77 \\ 0.86 & 0.99 & 0.98 & 1.00 & 1.47 & 0.91 \\ 0.07 & 0.04 & 0.31 & 0.60 & 1.12 & 0.47 \\ 8.21 & 8.97 & 10.65 & 10.18 & 12.91 & 8.74 \\ 0.44 & 1.24 & 1.31 & 2.38 & 3.28 & 3.37 \\ 2.77 & 0.79 & 0.72 & 0.61 & 0.44 & 1.08 \\ 6.47 & 6.31 & 9.33 & 6.31 & 5.07 & 5.09 \\ 0.74 & 0.76 & 0.40 & 0.28 & 0.31 & 0.69 \\ 3.31 & 4.04 & 3.25 & 13.29 & 5.77 & 8.56 \\ 27.84 & 30.59 & 11.45 & 11.43 & 14.03 & 12.06 \\ 0.45 & 0.65 & 0.69 & 0.49 & 0.40 & 0.52 \\ 1.33 & 1.67 & 1.61 & 1.47 & 2.48 & 2.03 \\ 0.02 & 0.04 & 0.01 & 0.09 & 0.26 & 0.20 \\ 0.04 & 0.06 & 0.05 & 0.13 & 0.04 & 0.04\end{array}$

Share of JAFF in firms in Japan

$\begin{array}{rrrrrr}1987 & 1988 & 1989 & 1990 & 1991 & 1992 \\ 0.25 & 0.27 & 0.27 & 0.28 & 0.30 & 0.28 \\ 0.84 & 0.89 & 0.92 & 0.93 & 0.97 & 0.96 \\ 0.27 & 0.18 & 0.19 & 0.22 & 0.28 & 0.22 \\ 0.02 & 0.01 & 0.02 & 0.14 & 0.16 & 0.14 \\ 6.23 & 8.41 & 9.63 & 9.11 & 10.51 & 9.64 \\ 0.27 & 0.77 & 0.75 & 0.76 & 0.97 & 1.00 \\ 1.48 & 0.76 & 0.68 & 0.73 & 0.81 & 0.50 \\ 1.84 & 2.04 & 2.00 & 2.19 & 1.95 & 2.10 \\ 0.23 & 0.32 & 0.38 & 0.20 & 0.20 & 0.33 \\ 1.22 & 1.34 & 1.12 & 1.50 & 1.98 & 2.35 \\ 22.88 & 21.57 & 20.37 & 20.40 & 18.65 & 19.19 \\ 0.12 & 0.14 & 0.17 & 0.14 & 0.11 & 0.14 \\ 0.20 & 0.25 & 0.23 & 0.24 & 0.33 & 0.25 \\ 0.01 & 0.01 & 0.01 & 0.02 & 0.05 & 0.04 \\ 0.03 & 0.03 & 0.02 & 0.03 & 0.02 & 0.01\end{array}$

Data sources: OLD87/88, 89, 90, 91, 92, AFB7/88, 89, 90, 91, 92, EPA94. 
w

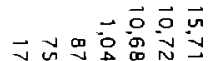

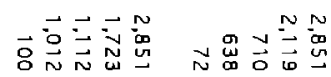

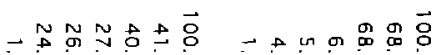

w出宫 $\overrightarrow{8} \sim N \sim \overrightarrow{8}$

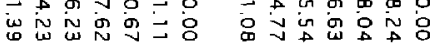

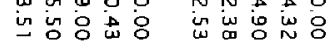

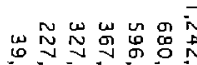

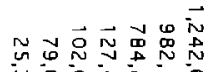

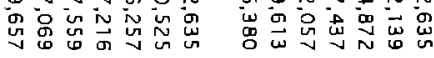

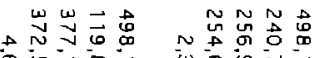

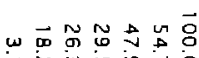

ก

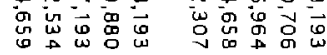

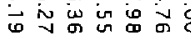

议等家品

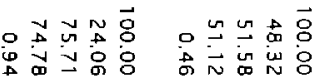

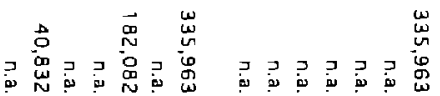

$\overrightarrow{0}$ in

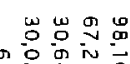

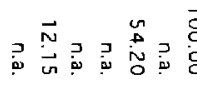

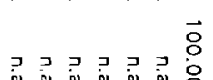

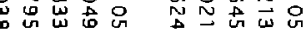

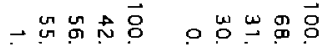

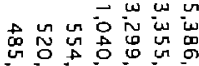

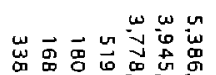

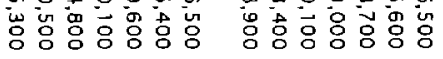

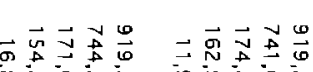

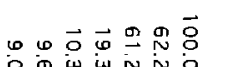

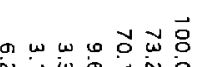

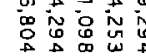

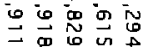

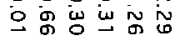

- $\vec{\sigma} \vec{\phi} \stackrel{0}{\circ} \vec{\circ}$

$\vec{\sim} \overrightarrow{0}$ o

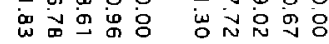

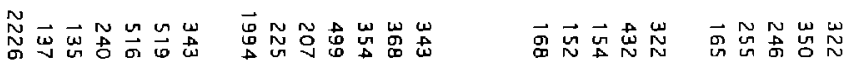

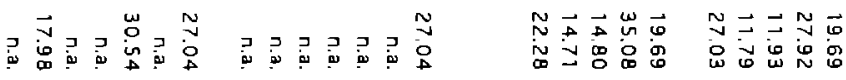

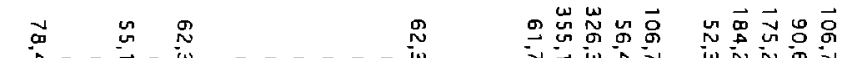

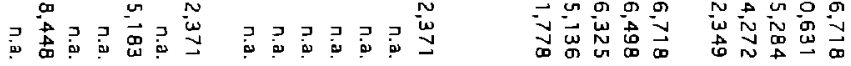

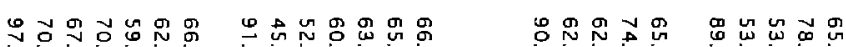

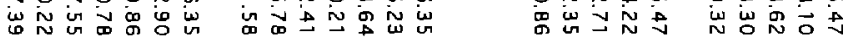

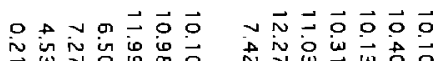

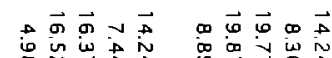

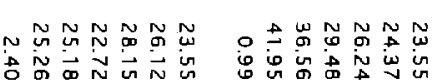

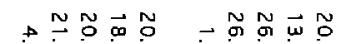

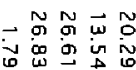

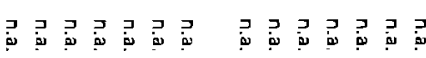

幽芯出

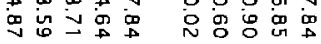

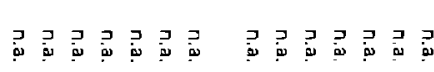

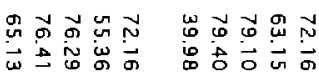

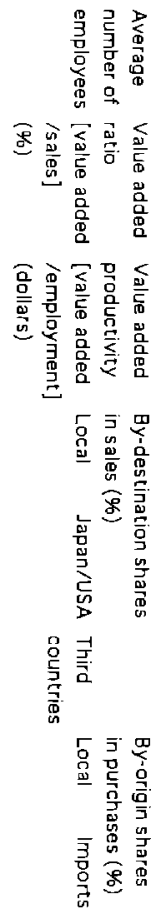


Table 7 Sales and Purchases by Commercial FAJF and Major Foreign Branches of Japanese General Trading Companies, 1987 (in millions of yen; \%)

GTC branches

Total sales
to local
to Japan
to third countries
Total purchases
from local
from Japan
From third countries

(a)

(b)

Commercial FAJF

$23,482,200$

$8,209,900$

$7,631,200$

$7,641,200$

$39,876,831$
$24,796,290$
$7,825,381$
$7,255,160$

\section{n.a.}

n.a.

n.a.

n.a.

$31,914,173$

$9,637,230$

$16,063,493$

$6,213,450$ (c)

Total FAJF

$54,808,975$

$36,219,960$

$9,294,170$

$9,294,845$ (d)

(a) $/($ b) $* 100$

(e)

All data are for 1987 financial year.

The data labelled as GTC branches are for major foreign branches of nine Japanese general trading companies, which include 197 affiliates in 37 countries.

The GTC branch data are originally in US dollars and are converted by IMF92, p. 437 ( $\$ 1=144.64$ yen).

By-destination sales by commercial FAJF and total FAJF are estimated by using sectoral by-destination ratios. See the text for details.

Data sources: GTC, OLD87/88. 
Figure 1

Estimation of Aggregate Net Sales

by Japanese to Foreigners, 1987

(in millions of yen)

\section{Japanese}

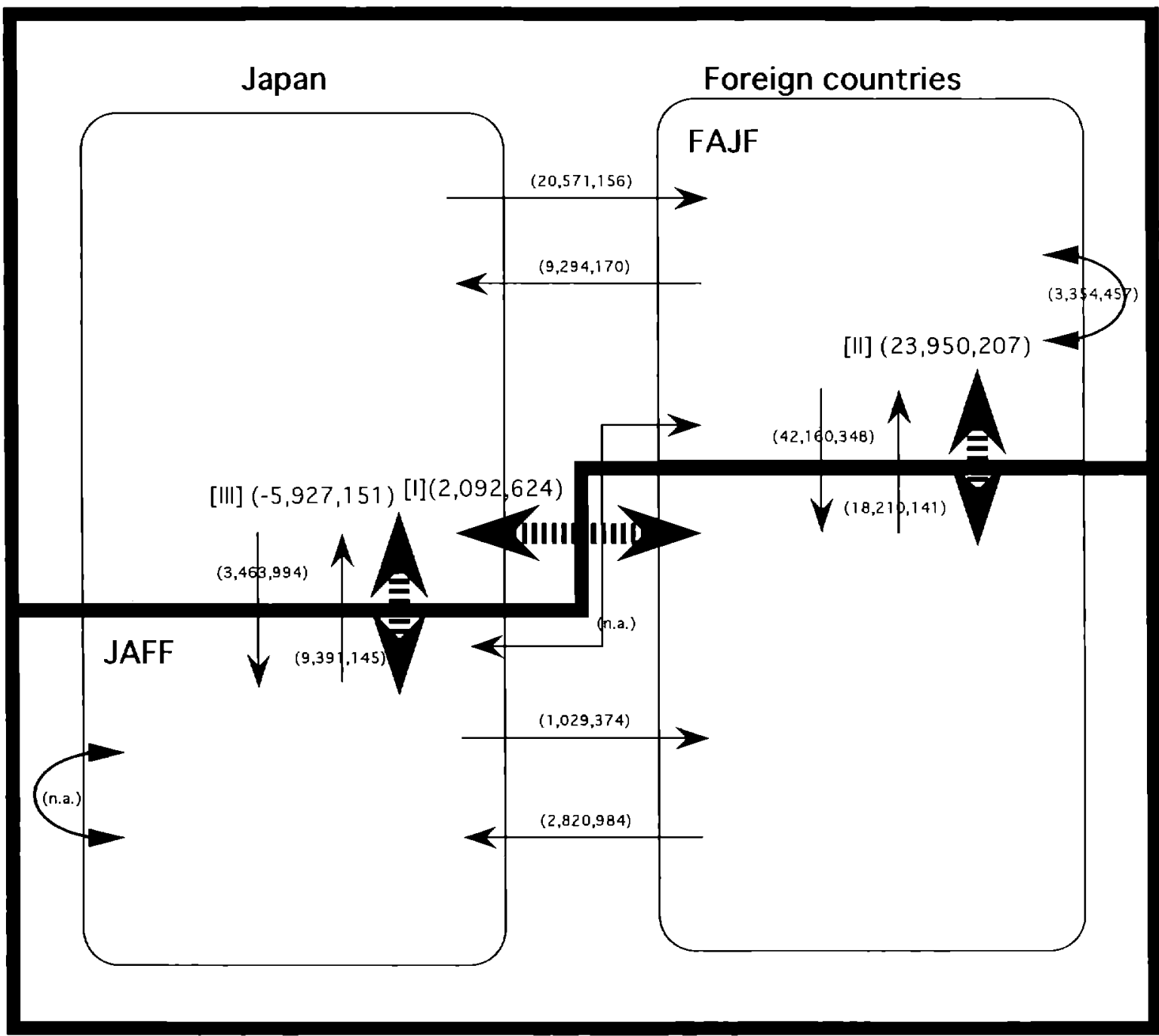

$(20,115,680)$

Foreigners

$(33,315,000)$

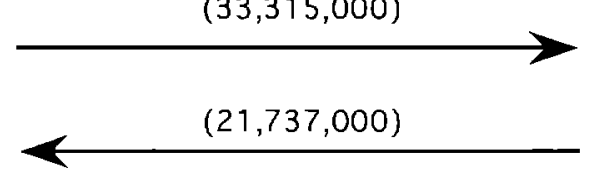

$(11,578,000)$

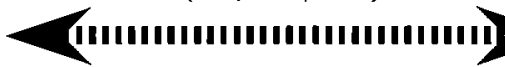


Figure 2

Estimation of Value Added

in Goods and Services Sold by FAJF and JAFF

and Exports of Japanese-Owned and

Foreign-Owned Firms, 1987

(in millions of yen)

\section{Japanese}

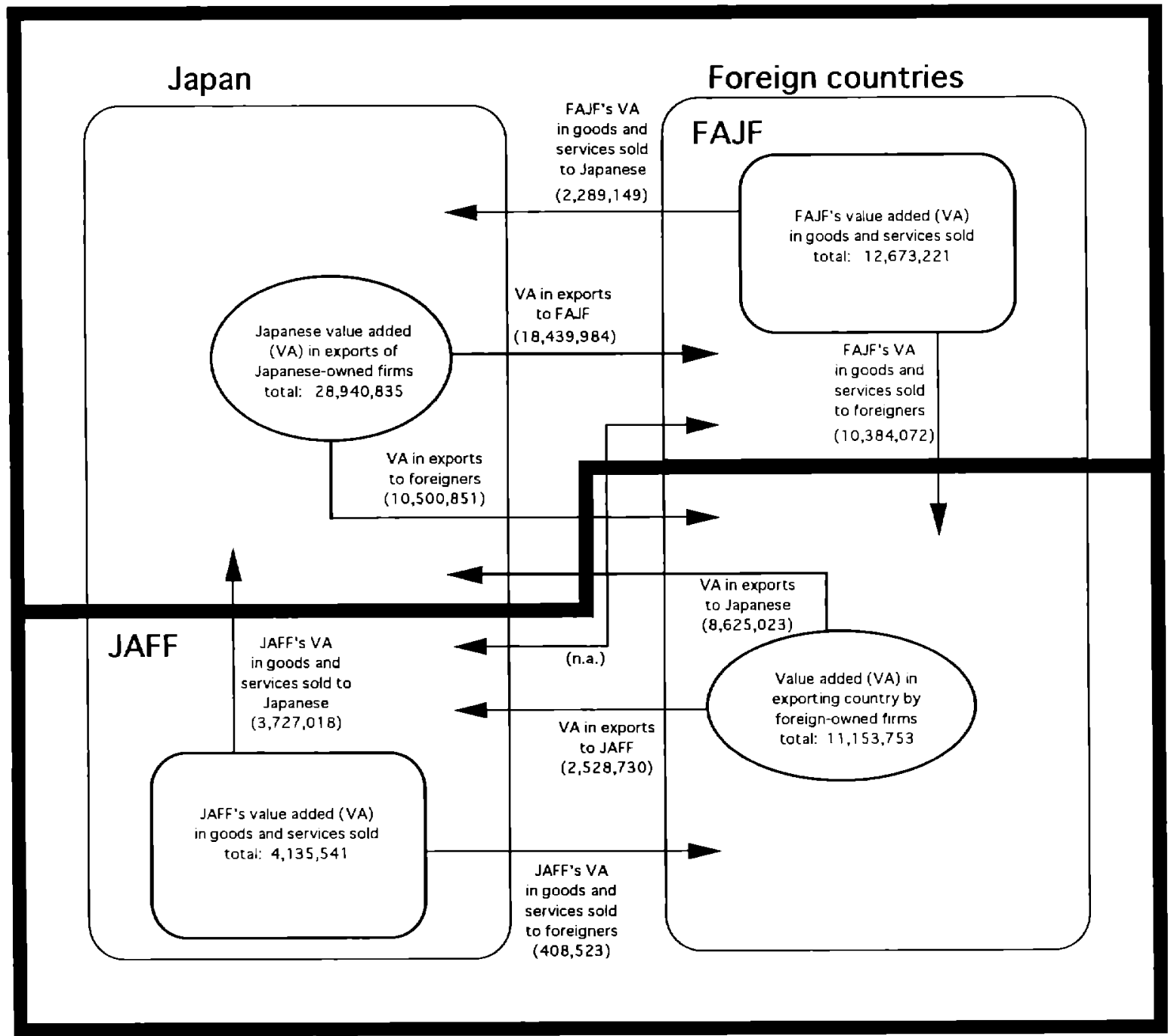

Foreigners 